\title{
Total Factor Productivity Growth in Pakistan: An Analysis of the Agricultural and Manufacturing Sectors
}

\author{
Azam Amjad Chaudhry
}

\begin{abstract}
This paper uses Cobb-Douglas and translog production functions to calculate total factor productivity (TFP) in Pakistan over the period 1985 2005, first for the manufacturing and agricultural sectors individually, then for the economy as a whole. In manufacturing, productivity increased at an average of $2.4 \%$ per year with output growth being driven mainly by increases in capital. Despite the limitations of the available agricultural data, we have determined that productivity has grown at an average rate of $1.75 \%$ per year in this sector. The major drivers of growth in agriculture have been increases in labor and TFP. These estimates of sectoral TFP put Pakistan at par or above average as compared to other developing countries, but lagging behind the East Asian economies. For the economy as a whole, TFP has increased at an average rate of only $1.1 \%$ a year in Pakistan, resulting in almost three quarters of GDP growth attributed to increases in labor and the capital stock.
\end{abstract}

JEL Classification: D24, E0, F4.

Keywords: Growth, capital, labor, total factor productivity.

\section{Introduction}

One of the fundamental questions that arises across all economies is how much of economic growth is caused by growth in physical and human capital and how much is caused by factors such as technology and institutional change. Though there is little doubt about the positive impact of increased physical and human capital on growth, most economists feel that sustained high growth is dependent on sustained technological and institutional growth. Based on the assumptions of constant returns to scale and competitive factor markets, one can calculate the growth rate implied by the rates of change in physical and human capital and find the deviations of the actual growth rate from this implied growth rate. These deviations

\footnotetext{
* Associate Professor and Dean, Department of Economics, Lahore School of Economics.
} 
are the result of technological and institutional change and are called growth in total factor productivity (TFP). The objective of this paper is to analyze the growth rates of TFP in Pakistan's agricultural and manufacturing sectors over the last two decades and see how they compare to TFP growth rates in other developing countries.

Most economic analyses of TFP growth focus on gross domestic product (GDP) growth across countries instead of manufacturing and agricultural sector growth. The reason that a disaggregated analysis is meaningful in the context of a developing country like Pakistan is because of the prevailing view that agricultural productivity growth is significantly lower than manufacturing productivity growth. This has extremely important policy implications. First, if agricultural productivity is perceived to be perpetually lower than manufacturing productivity, then policymakers will tend to bias policies and incentive structures toward manufacturing (which has generally been the case in Pakistan). Second, if agricultural productivity is perceived to be lower than manufacturing productivity, then research resources and technology adoption will be more heavily directed toward the manufacturing side. Finally, if agricultural productivity is perceived to be lower than manufacturing productivity, then policymakers may become perpetually reliant on the existing manufacturing structure as the driver of growth and less willing to create incentives to allow risky diversification in the manufacturing sector.

The reason for undertaking a sectoral analysis of TFP growth is because the cross-country empirical evidence is far from clear: Hayami and Ruttan (1985) found a number of examples of rapid technological change in agriculture; Bernard and Jones (1996) and Syrquin (1986) found much higher rates of growth in agricultural TFP relative to other sectors. This means that comparing manufacturing and agricultural sector TFP growth rates could be useful in the Pakistani context.

The structure of this paper is as follows: Section II discusses how TFP growth is estimated. Section III looks at some of the recent analyses on Pakistani TFP growth. Section IV looks at the data. Section V presents the results of the analysis, and Section VI presents the conclusions.

\section{Section II: Defining TFP}

There are numerous debates about the causes and consequences of economic growth and, at the same time, about the specific sources of economic growth. In developing countries like Pakistan, an important question that arises is how much growth in income per capita is due to 
increases in physical and human capital per person and how much is due to factors such as technological change, institutional change, and other factors. In a pure accounting sense, that part of economic growth that is not explained by accumulations in capital and labor is assumed to be explained by TFP or factors such as technological and institutional change.

The process of separating out the impact of increases in physical and human capital from increases in TFP is called 'growth accounting' and was pioneered by Solow (1956, 1957) and Abramovitz (1956). It is based on calculating the deviations of actual output growth from output growth implied by the growth rates of physical and human capital (under the assumptions of constant returns to scale and competitive factor markets). This 'deviation' of actual from implied growth rates (also known as the 'Solow residual') can be calculated as follows:

Using a production function that allows for Hick's neutral productivity change:

$$
\mathrm{Y}=\mathrm{AK}^{\alpha} \mathrm{L}^{(1-\alpha)}
$$

where $\mathrm{Y}$ is output, $\mathrm{L}$ is labor employed, $\mathrm{K}$ is capital employed, and $\mathrm{A}$ is a Hicks neutral productivity term which represents TFP.

Taking logs and differentiating over time gives us:

$$
\frac{\dot{Y}}{Y}=\propto\left(\frac{\dot{K}}{K}\right)+(1-\propto)\left(\frac{L}{L}\right)+\frac{\dot{A}}{A}
$$

This last equation states that output growth is simply equal to a weighted average of the growth rates in capital and labor plus the growth rate of TFP. Thus, using the rates of change of output, capital, and labor, one can estimate the rate of change of TFP.

A slightly different methodology for measuring the TFP growth rate was adopted by Martin and Mitra (1999) and used a log-linear function:

$$
\ln Y_{t}=\ln A_{0}+r_{t}+\alpha \ln L_{t}+\beta \ln K_{t}
$$

where $r$ is the TFP growth rate in a regression of $\log$ of output on a time trend, the $\log$ of labor and the $\log$ of capital and $\mathrm{A}_{0}$ is the initial TFP level. As above, Martin and Mitra (1999) assume constant returns to scale $(\alpha+\beta=1)$. 
Martin and Mitra (1999) also use the translog production function introduced by Christensen, Jorgenson, and Lau (1973), which provides a second-order approximation to an arbitrary functional form and is the general form of the Cobb-Douglas and Constant Elasticity of Substitution production functions. The two-input translog production can be written as:

$\ln Y_{t}=\ln A_{0}+r_{t}+\beta_{1} 1 n L_{t}+\beta_{2} \operatorname{lnK}_{t}+\beta_{3} \ln K_{t} 1 n L_{t}+(1 / 2) \beta_{4}\left(1 n K_{t}\right)^{2}+(1 / 2) \beta_{5}\left(\operatorname{lnL}_{t}\right)^{2}$

Using this form, we can also assume symmetry $\left(\beta_{3}+\beta_{4}=0\right.$ and $\left.\beta_{3}+\beta_{5}=0\right)$ and constant returns to scale $\left(\beta_{2}+\beta_{2}=1\right)$.

At this stage it is important to point out the limitations of estimating TFP. The TFP growth rate in the equation above may not accurately represent technological change since measurement errors in output, labor, and capital can lead to errors in calculating productivity over time. A simple illustration is when a country builds a useless road with a marginal product of zero: this shows up as a positive increase in the capital stock but since it does not increase output, it leads to a decrease in the estimated TFP growth rate. Similarly, if the average number of hours worked by labor increases, it emerges as an increase in TFP growth, though effectively, there has been no change in productivity. In addition, it must be noted that many economists include a 'human capital' element in the production function, which roughly measures a worker's average level of education, since it is not simply the amount of labor that determines output but also the quality of labor (i.e., more educated labor will be able to produce more output). Besides these limitations, cross-country comparisons of TFP changes are too great to be simply due to measurement errors and for this reason an analysis of TFP growth rates is useful in determining the overall trend in productivity over time.

\section{Section III: TFP Growth in Pakistan}

Recent analyses of TFP growth in Pakistan present a varied picture. Martin and Mitra (1999) look at productivity growth in the agriculture and manufacturing sectors from 1967 to 1992 using data on 38 countries (23 developing and 13 developed countries) for their analysis of the manufacturing sector, and 49 countries (32 developing and 15 developed countries) for the agricultural sector. In their entire sample, the average growth rate of TFP in manufacturing ranged from $1.13 \%$ to $1.86 \%$ (depending on the specification used) while the average growth of TFP in agriculture ranged from $2.34 \%$ to $2.91 \%$ (again, depending on the specification used). For developing countries, the TFP growth rate in manufacturing ranged from $0.62 \%$ to $0.92 \%$ and the TFP growth rate in agriculture ranged from $1.76 \%$ to $2.62 \%$. As the numbers 
show, across countries, the TFP growth rate in manufacturing was significantly lower than the TFP growth rate in agriculture. The TFP growth rates for Pakistan were interesting in that the TFP growth rates for manufacturing and agriculture were not significantly different. Depending on the specification used, the TFP growth rate in manufacturing ranged from 1.4 to 2.33 and the TFP growth rate in agriculture ranged from 1.7 to 2.3. Thus, Pakistan stands out for having approximately the same TFP growth rates across sectors though this is primarily due to a lower TFP growth rate in agriculture.

Another widely cited paper by Klenow and Rodriguez-Claire (1997) looks at TFP growth across countries, in which it uses a more widely defined measure of human capital rather than labor. This measure of human capital is defined as the amount of labor multiplied by the amount of human capital per worker, which is estimated using secondary school enrollment rates. Using this decomposition, the authors find that Pakistan's TFP growth rate from 1960 to 1985 averages $2.68 \%$, which is higher than the average TFP growth rate across countries.

Baier, Dwyer, and Tamura (2006) also look at TFP growth across 145 countries, again using the more widely defined measure of human capital instead of labor. For data from 1960 to 2000, they find that, across all countries, the weighted TFP growth (weighted by population) averaged just $0.22 \%$ and the weighted TFP growth rate for Asia was also $0.22 \%$. For the period 1951-2000, they find that the TFP growth rate for Pakistan was 0.19 or, in other words, TFP in Pakistan had fallen.

\section{Section IV: Data}

For this study, the large-scale manufacturing sector and agricultural sector were analyzed. The analysis of TFP growth in each sector is challenging because of data limitations (both in terms of availability and accuracy), but an attempt was made to obtain a consistent dataset using information from the Economic Surveys of Pakistan, the Agricultural Statistics of Pakistan, the Census of Manufacturing Industries, and the Labour Force Surveys of Pakistan.

For the manufacturing sector, data from 1985 to 2005 was gathered for value-added, average daily employment, and value of fixed assets in largescale manufacturing. The data for these variables were taken primarily from the Census of Manufacturing Industries and the Economic Surveys of Pakistan. For the agricultural sector, data from 1990 to 2005 was gathered on the total value of major crops, the labor employed in agriculture, the total cropped area, and the value of key inputs. The data for these variables 
was taken primarily from the Agricultural Statistics of Pakistan and various issues of the Economic Survey of Pakistan.

The figures below show changes in the data over time. Figure 1 shows manufacturing output and labor and capital inputs from 1985 to 2005 . The useful thing to note is the strong correlation between manufacturing output and capital inputs over time. This is further illustrated in Figure 2, which shows the relationship between manufacturing output growth and the growth in labor and capital inputs. The reason that the relationship between growth rates is important is because the stronger the relationship between manufacturing output growth and input growths, the weaker is productivity growth. In other words, if manufacturing sector growth is purely the result of input growth, then there is no productivity growth.

Figure-1: Manufacturing Output, Employment, and Capital Stock (19852005)

- Real Value Added in Manufacturing (Rs Billion) $\rightarrow$ Average Daily Employment (Tens of Thousands)
- Real Value of fixed Assets (Rs Billion)

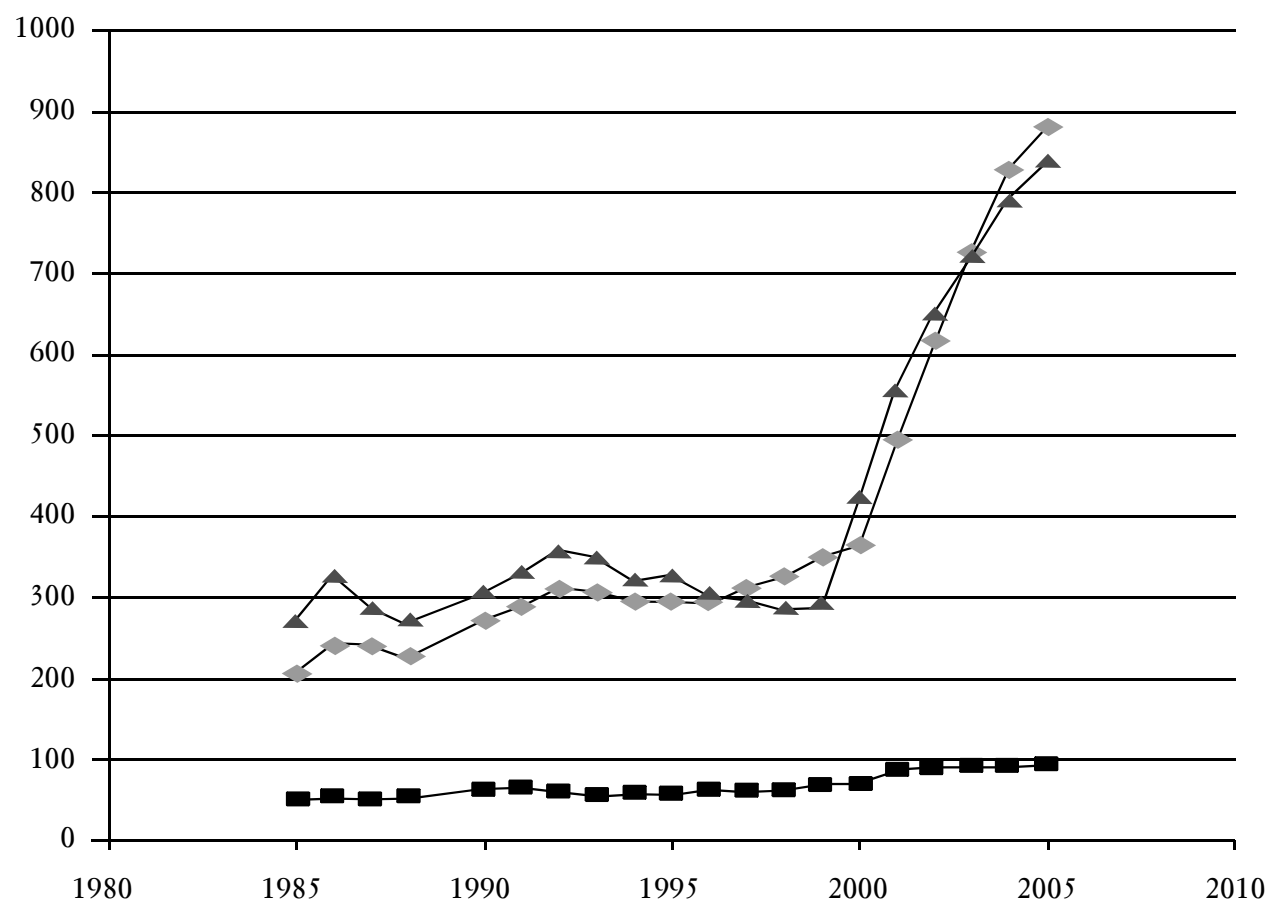


Figure-2: Growth Rates in Manufacturing Output, Employment, and Capital Stock (1985-2005)

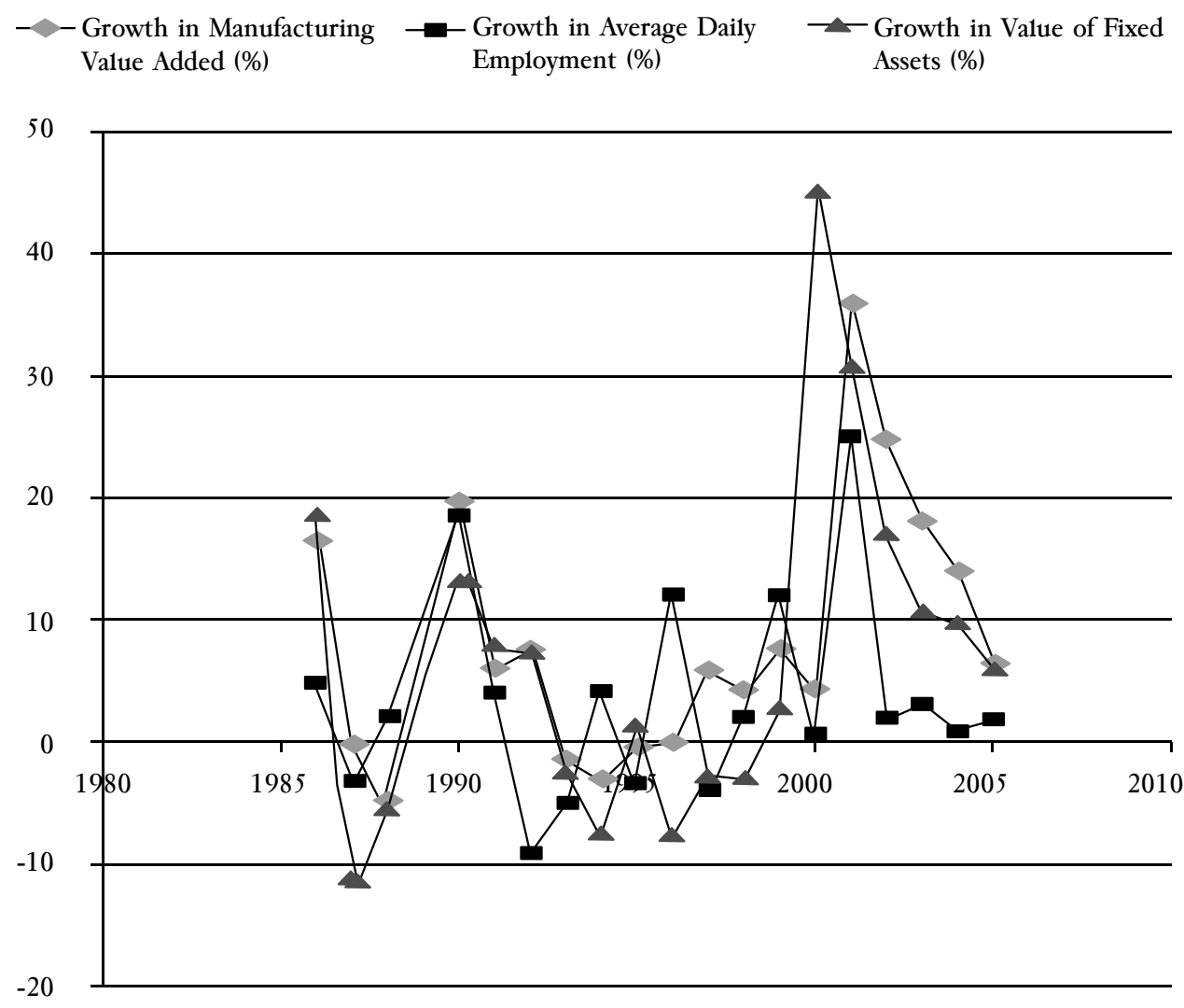

Figures-3 and 4 show the relationship between agricultural output and agricultural inputs over time. As the figures show, fertilizer inputs, the number of tubewells, and the number of tractors all seem to follow the same trend as agricultural output. Again, the important issue becomes the relationship between agricultural output growth and input growth, when determining productivity growth. 
Figure-3: Agricultural Output and Inputs (1990-2005)

\begin{tabular}{|c|c|c|}
\hline- DefVal & $\begin{array}{r}- \text { Labour Employed in } \\
\text { Agriculture (million) }\end{array}$ & $\begin{array}{c}\text { Total Cropped area } \\
\text { (million acres) }\end{array}$ \\
\hline$\nrightarrow \leftarrow$ Water & $\rightarrow \leftarrow$ Fertilizer & - Tractors \\
\hline
\end{tabular}

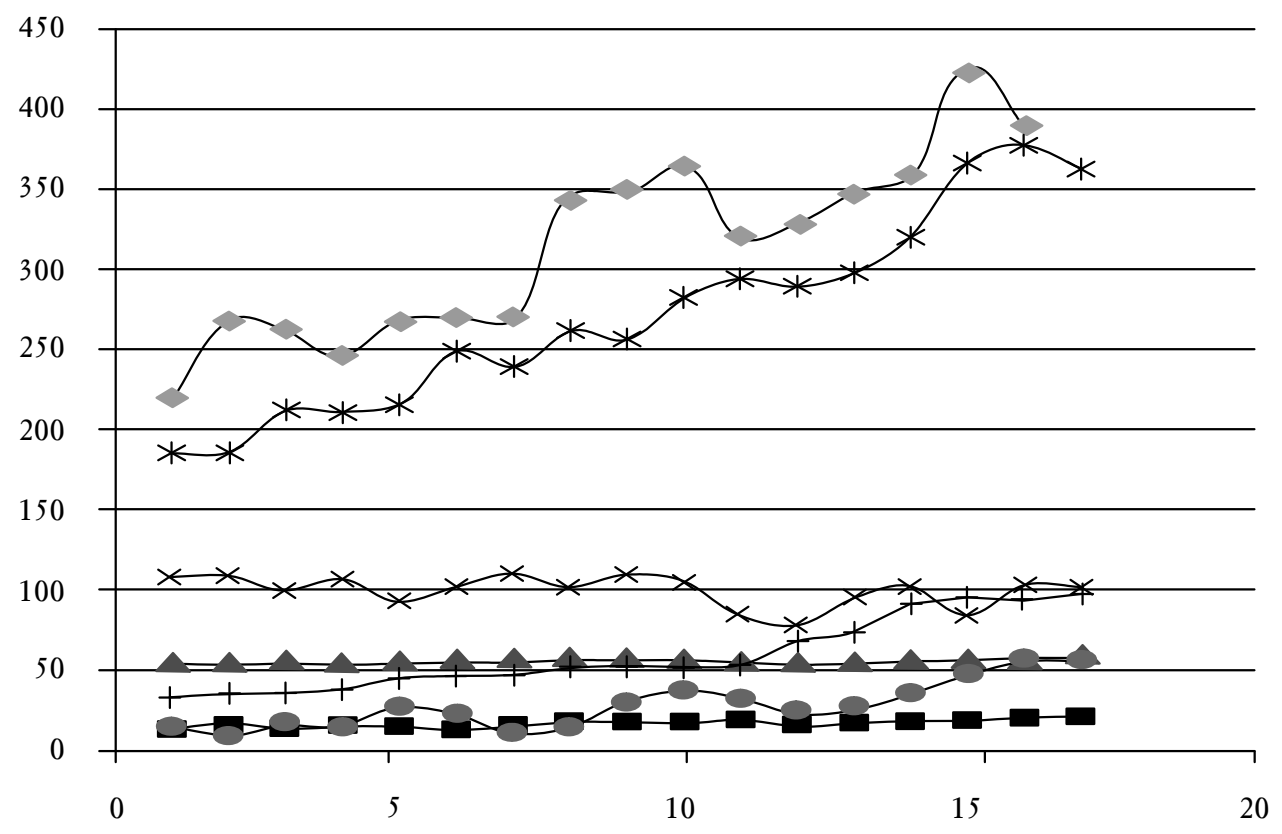


Figure-4: Growth Rates of Agricultural Output and Selected Inputs (1990-2005)

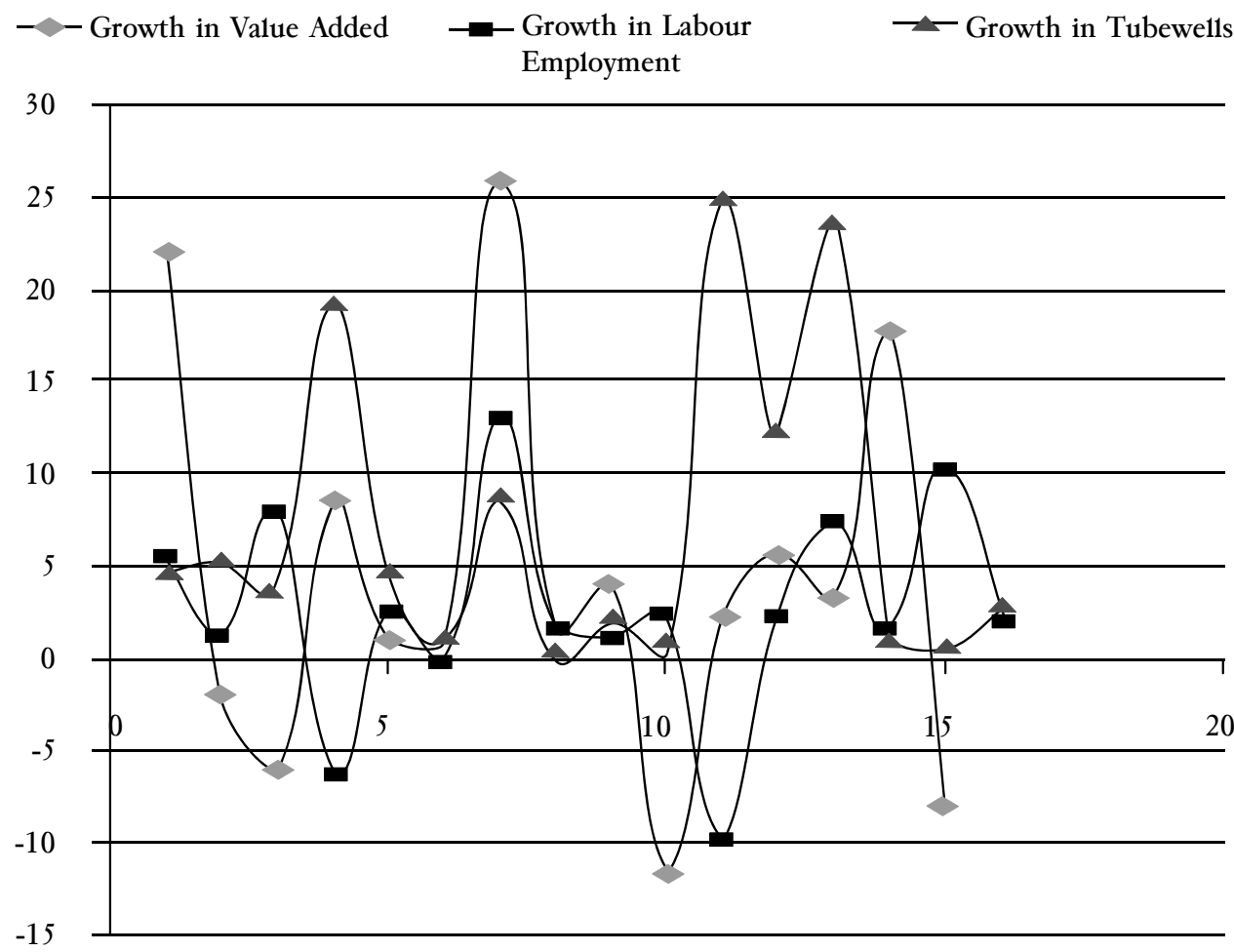

\section{Section V: Results}

Following Martin and Mitra (1999), production functions were estimated both for the manufacturing sector and agricultural sector. For the agricultural sector, estimates were obtained using the Cobb-Douglas production function (with the constraint of constant returns to scale imposed), while estimates for the manufacturing sector were obtained using both the Cobb Douglas production function and the translog production function (also with the constraint of constant returns to scale).

In the Cobb-Douglas specification, TFP growth over the period 1985 to 2005 averaged $2.48 \%$ per year in the manufacturing sector while in the translog specification, TFP growth averaged $2.40 \%$ per year ${ }^{1}$. This is slightly higher than Martin and Mitra's (1999) estimates of manufacturing sector TFP growth from 1967 to 1992 for the Pakistani manufacturing sector,

\footnotetext{
${ }^{1}$ Note that for the sake of consistency, the TFP growth rate for manufacturing was also calculated for the period 1990-2005 (which is the same period under analysis in the agricultural sector) and the TFP growth rate was still found to be $2.4 \%$ per year.
} 
which averaged $1.4 \%$ per year in the Cobb-Douglas specification and $2.33 \%$ per year in the translog specification.

A detailed breakdown of the growth in the manufacturing sector is provided in Tables-1 and 2. As Table-1 shows, the average growth rate of large-scale manufacturing output is $7.8 \%$ between 1985 and 2005 . During this period, capital stock grew at an average of $6.6 \%$ a year, the labor force grew at $3.5 \%$ per year, and TFP grew at $2.4 \%$ per year. Table- 2 presents an interesting breakdown of the components of manufacturing sector growth ${ }^{2}$ : $56 \%$ of total large-scale manufacturing sector growth was due to growth in capital stock, $15 \%$ was due to growth in labor, and $29 \%$ was due to growth in TFP. Thus, it is clear that manufacturing sector growth has been driven primarily by increases in capital and not increases in productivity.

\section{Table-1: Average Growth Rates in the Large Scale Manufacturing Sector, 1985-2005 (\%)}

\begin{tabular}{cccc}
\hline $\begin{array}{c}\text { Large-Scale } \\
\text { Manufacturing } \\
\text { Output }\end{array}$ & $\begin{array}{c}\text { Large-Scale } \\
\text { Manufacturing } \\
\text { Capital Stock }\end{array}$ & $\begin{array}{c}\text { Large-Scale } \\
\text { Manufacturing } \\
\text { Labor }\end{array}$ & $\begin{array}{c}\text { Total Factor } \\
\text { Productivity }\end{array}$ \\
\hline $7.8 \%$ & $6.6 \%$ & $3.53 \%$ & $2.4 \%$ \\
\hline
\end{tabular}

Table-2: Components of Large-Scale Manufacturing Sector Growth, 1985-2005 (\%)

\begin{tabular}{ccc}
\hline $\begin{array}{c}\text { Growth in Capital } \\
\text { Stock }\end{array}$ & Growth in Labor & $\begin{array}{c}\text { Growth in Total Factor } \\
\text { Productivity }\end{array}$ \\
\hline $56 \%$ & $15 \%$ & $29 \%$ \\
\hline
\end{tabular}

It is also useful to compare these estimates to the results obtained by Martin and Mitra (1999) for TFP growth in the manufacturing sector for other countries. For low-income countries, they obtained estimates ranging from $0.22 \%$ (for the Cobb-Douglas specification) to $0.93 \%$ (for the translog specification) for the average TFP growth rate in manufacturing. For middleincome countries, they obtained estimates of average manufacturing sector TFP growth rates of $0.62 \%$ to $0.92 \%$. The results imply that Pakistan has a higher manufacturing sector TFP growth rate than average, but that this growth rate is significantly lower that the manufacturing sector TFP growth rates for the major East Asian economies that ranged from 4 to $6 \%$ per year.

${ }^{2}$ The shares of capital and labor were taken from the estimated Cobb-Douglas functional forms and are consistent with the shares used by other authors, including Martin and Mitra (1999). 
For the agricultural sector, only the Cobb-Douglas specification was tested and the estimated TFP growth rate over the period 1990 to 2005 was equal to $1.75 \%$ per annum. ${ }^{3}$ This is the approximately the same as Martin and Mitra's (1999) estimates for agricultural productivity growth from 1967 to 1992 of $1.7 \%$ per year for the Cobb-Douglas form, though the estimated translog form gave an estimated productivity growth of $2.33 \%$ per year. The results in this study are lower than those of Khan (1994), who found an average annual TFP growth rate for agriculture of $2.4 \%$ for the period 1980 to 1993, but higher than those of Khan (1997) and Kemal et a1 (2002), who found average agricultural TFP growth rates of $0.92 \%$ (for 1960-1996) and $0.37 \%$ (for 1965-2001).

A detailed breakdown of the growth in the agricultural sector is provided in Tables-3 and 4. As Table-3 shows, the average growth rate of agricultural output was $3.57 \%$ between 1990 and 2005. During this period, agricultural labor increased by $2.09 \%$ per year, agricultural land increased by $0.2 \%$ per year, the number of tubewells increased by $7.03 \%$ per year, the number of tractors increased by $9.1 \%$ per year, the amount of fertilizer used increased by $4.37 \%$ per year, water decreased by an average of $0.79 \%$ per year, and TFP grew at $1.75 \%$ per year. Table- 4 presents an interesting breakdown of the components of agricultural sector growth $^{4}: 40 \%$ of total agricultural sector growth was due to growth in labor, $49 \%$ was due to growth in TFP, and $11 \%$ was due to growth in other factors of production. These results show that agricultural sector growth has been low and been driven primarily by growth in labor and productivity. However, these results have to be viewed more critically than the results obtained from the manufacturing sector because the unreliability of agricultural input data may have led to underestimating the contribution of other factors in agricultural sector growth and overestimating the TFP growth rate.

Table-3: Average Growth Rates in the Agricultural Sector, 1990-2005 (\%)

\begin{tabular}{cccccccc}
\hline $\begin{array}{c}\text { Agricultural Agricultural } \\
\text { Output }\end{array}$ & $\begin{array}{c}\text { Agricultural } \\
\text { Labor }\end{array}$ & $\begin{array}{c}\text { Surface } \\
\text { Land }\end{array}$ & $\begin{array}{c}\text { Tube- } \\
\text { wells }\end{array}$ & Tractors & Fertilizer & $\begin{array}{c}\text { Total Factor } \\
\text { Productivity }\end{array}$ \\
\hline $3.57 \%$ & $2.09 \%$ & $0.2 \%$ & $-0.79 \%$ & $7.03 \%$ & $9.1 \%$ & $4.37 \%$ & $1.75 \%$ \\
\hline
\end{tabular}

\footnotetext{
${ }^{3}$ The translog form was not estimated because of the limited degrees of freedom.

${ }^{4}$ The shares of capital and labor were taken from the estimated Cobb-Douglas functional forms and are consistent with the shares used by other authors, including Martin and Mitra (1999).
} 
Table-4: Components of Agricultural Sector Growth, 1990-2005 (\%)

\begin{tabular}{ccc}
\hline Growth in Labor & $\begin{array}{c}\text { Growth in Total Factor } \\
\text { Productivity }\end{array}$ & $\begin{array}{c}\text { Growth in Other } \\
\text { Factors of Production }\end{array}$ \\
\hline $40 \%$ & $49 \%$ & $11 \%$ \\
\hline
\end{tabular}

As was done earlier for the manufacturing sector, the figures above can be compared to the estimates obtained for other countries. For lowincome countries, Martin and Mitra (1999) obtain an average agricultural TFP growth rate of $1.44 \%$. For developing countries, they obtain an estimate of $1.76 \%$ for the agricultural TFP growth rate. The results seem to imply that Pakistani agricultural productivity growth has not been especially slow, but it should be noted that that agricultural TFP growth rate for the East Asian economies ranged from 2.5 to $4 \%$.

A final analysis is carried out for the entire economy to compare TFP growth in agriculture and manufacturing to overall TFP growth. The work on TFP growth is fairly well advanced with authors like Klenow and Rodriguez-Claire (1997), Barro and Lee (1999), Hall and Jones (1999), and Baier, Dwyer, and Tamura (2006) who have developed both the models and data to obtain meaningful cross-country analysis. The analysis done in this paper simply estimates an economy-wide Cobb-Douglas production function (with constant returns to scale) using data on GDP, capital stock, and employment for the period 1985 to 2005 . One of the most obvious limitations of this analysis is that a measure of human capital is not included (which most other authors do include), which might overestimate the average TFP growth rate. Nonetheless, the exercise is still useful in assessing the general trend in TFP over time in Pakistan.

The results for the GDP growth are shown in Tables-5 and 6. As Table- 5 shows, the average growth rate of GDP is $4.1 \%$ between 1985 and 2005 . During this period, capital stock grew at an average of $4.2 \%$ a year, the labor force grew at $2.4 \%$ per year, and TFP grew at $1.1 \%$ per year. Table-6 presents a breakdown of the components of GDP: $33 \%$ of GDP growth was due to growth in capital stock, $40 \%$ was due to growth in labor, and $27 \%$ was due to growth in TFP. It can be clearly seen that overall growth in Pakistan has been driven primarily by increases in capital and labor, not increases in productivity. 
Table-5: Average Growth Rates in Pakistan, 1985-2005 (\%)

\begin{tabular}{cccc}
\hline GDP & Capital Stock & Labor & Total Factor Productivity (TFP) \\
\hline $4.1 \%$ & $4.2 \%$ & $2.4 \%$ & $1.1 \%$ \\
\hline
\end{tabular}

Table-6: Components of GDP Growth, 1985-2005 (\%)

\begin{tabular}{ccc}
\hline $\begin{array}{c}\text { Growth in Capital } \\
\text { Stock }\end{array}$ & $\begin{array}{c}\text { Growth in } \\
\text { Labor }\end{array}$ & $\begin{array}{c}\text { Growth in Total Factor } \\
\text { Productivity }\end{array}$ \\
\hline $33 \%$ & $40 \%$ & $27 \%$ \\
\hline
\end{tabular}

The numbers for the economy as a whole are not extremely different from estimates obtained from other cross-country analyses: Klenow and Rodriguez-Claire estimated Pakistani TFP growth from 1960 to 1985 to be 2.68\%, and Baier, Dwyer, and Tamura estimated Pakistani TFP growth from 1951 to 2000 to be $-0.19 \%$. Again, it should be noted that if human capital is incorporated into the analysis, then any significant increases in human capital over that period will lead to a fall in the estimated TFP growth rate.

\section{Section VI: Conclusions}

The results of the analysis in this paper imply that TFP in the manufacturing sector has grown at a higher rate than TFP in the agricultural sector over the last two decades in Pakistan. On the manufacturing side, productivity is increasing at an average of $2.4 \%$ per year while output growth is being driven by increases in capital. On the agricultural side, productivity is growing at an average rate of $1.75 \%$ per year (though this is probably overestimated due to data limitations). With the available data, the major drivers of agricultural sector growth are labor and TFP growth. For the economy as a whole, TFP is increasing at an average rate of $1.1 \%$ a year, but almost three quarters of GDP growth is caused by increases in labor and capital stock.

Cross-country analyses find that high-growth economies are driven both by growth in their inputs as well as sustained growth in their productivity. The interesting aspect of this conclusion is not that productivity growth has to be extremely high, but simply sustained over a long period. The results in this analysis show that productivity growth in Pakistan at the sectoral level and at the aggregate level has been slow, and that growth has been input-driven rather than productivity-driven. When looking at the TFP growth experiences of other countries, one finds that 
factors such as human capital development, physical capital development (including infrastructure), financial development, technology absorption, and openness (especially in terms of openness to imports) have a significant impact of TFP growth. Until Pakistan focuses on these issues, growth will remain unsustainable. 


\section{References}

Abramovitz, M. (1956), Resource and Output Trends in the United States Since 1870. American Economic Review, Papers and Proceedings 46 (May) : 5-23.

Ahmad, K., Chaudhary, M.A., and Ilyas, M. (2008). Trends in Total Factor Productivity in Pakistan Agriculture Sector. Pakistan Economic and Social Review, 48 (2) : 117-132.

Baier, S., Dwyer, G., and Tamura, R. (2006). How Important are Capital and Total Factor Productivity for Economic Growth? Economic Inquiry, 44 (1) : 23-49.

Barro, R., and Lee, J.W. (1999). Notes on Growth Accounting. Journal of Economic Growth, 4 : 119-137.

Bernard, A., and Jones, C. (1996). Productivity Across Industries and Countries: Time Series Theory and Evidence. Review of Economics and Statistics, LXXVIII (1) : 135-146.

Christensen, L., Jorgensen, D., and Lau, L. (1973). Transcendental Logarithmic Production Frontiers. Review of Economics and Statistics, : 28-45.

Government of Pakistan (2007). Agricultural Statistics of Pakistan: 20062007. Ministry of Food Agriculture and Livestock, Islamabad.

Government of Pakistan (Various Years). Pakistan Economic Survey. Ministry of Finance, Islamabad.

Hall, R., and Jones, C. (1999). Why Do Some Countries Produce So Much More Output per Worker Than Others? Quarterly Journal of Economics, 114 (1) : 83-116.

Hayami, Y., and Ruttan, V. (1985). Agricultural Development: An International Perspective, Johns Hopkins University Press, Baltimore.

Kema1, A.R., Din, M., and Qadir, U. (2002). Global Research Project: Pakistan Country Report. Pakistan Institute of Development Economics, Islamabad. 
Khan, M.H. (1994). The Structural Adjustment Process and Agricultural Change in Pakistan in the 1980s and 1990s. The Pakistan Development Review, 33 (4) : 533-591.

Khan, M.H. (1997). Agricultural 'Crisis' in Pakistan: Some Explanations and Policy Options. The Pakistan Development Review, 36 (4) : 419-459.

Klenow, P., and Rodriguez-Claire, A. (1997). The Neoclassical Revival in Growth Economics: Has it Gone Too Far? National Bureau of Economic Research Annual Conference Papers, 73-102.

Martin, W., and Mitra, D. (1999). Productivity Growth and Convergence in Agriculture and Manufacturing. World Bank Working Paper Number 2171, World Bank, Washington DC.

Rosegrant, M., and Evenson, R. (1993). Agricultural Productivity Growth in Pakistan and India: A Comparative Analysis. The Pakistan Development Review, 32 (4) : 433-451.

Solow, R. (1956). A Contribution to the Theory of Economic Growth. Quarterly Journal of Economics, 70 : 65-94.

Solow, R. (1957). Technical Change and the Aggregate Production Function. Review of Economics and Statistics, 39 : 312-320.

Syrquin, M. (1986). Productivity Growth and Factor Reallocation, in Chenery, Robinson and Syrquin, eds. Industrialization and Growth: A Comparative Study, Oxford University Press for the World Bank, Oxford. 